\title{
Articles
}

\author{
MaKhaCh Musaev
}

\section{The Prohibition of Alcohol in Islam: Religious Imperatives and Practices in Seventeenth- to Nineteenth-Century Dagestan}

Translated by Margaret Berggren

DOI: $10.22394 / 2311-3448-2017-4-1-4-25$

Makhach Musaev - Institute of History, Archeology and Ethnography of the Dagestan Scientific Center of the Russian Academy of Sciences (Makhachkala, Russia). mahachmus@yandex.ru

Despite the well-known alcohol prohibition in Islam, in their everyday lives, throughout many places and times, Muslims have drunk alcohol. In this study, the religious prohibition and its practices are discussed in the context of the bicentennial history of Dagestan (since its final annexation by the Russian Empire). The article draws upon religious prescriptions in the works of the Shafi' (al-Nawawiand others) and Hanafi (al-Samarqandi and others) jurists, comparing them with evidence described and analyzed by scholars, foreign travelers (Adam Olearius, Evliya Çelebi, J. A. Güldenstädt, etc.), as well as local theological, legal, and historical works in the Arabic language.

Keywords: Dagestan, alcohol in Islam, Shaf'i, Hanafi, khamr, nabidh, al-Quduqi, al-Aymaki.

The Russian version of this article was previously published in: Gosudarstvo, religiia, tserkov'v Rossii i za rubezhom, 2016, 34 (4): 91-117.

This research was supported by Rossíiskii fond fundamentál'nykh isslédovanii (RFFI) grant №15-01-00389. 
I $\mathrm{T}$ is well known that Arabs of the "Jahiliyyah" period' were aware of methods for producing alcoholic drinks and liked to use them. Corresponding ayahs (verses) of the Qur'an, hadith, South Arabian, Palmyrene, and Nabataean inscriptions, pre-Islamic Arabian poetry, written records, et cetera, provide evidence of this. In Kitab al-Mukhassas, Ibn Sidah² (d. 1066) cited almost one hundred Arabic synonyms of the term wine, and in al-Firuzabadi's (d. 1415) "wine list" there are 357. The variety of nomenclature indicates that alcohol was a part of Arab daily life and culture. They drank not only wine (khamr, a derivative of grapes and dates), but also other alcoholic drinks produced by the fermentation of honey, fruit, cereals, dried fruits, and dried berries (mizr, bit', gubaira' and many others) (Maraqten 1993, 95-96; Waines 2011, xiii).

Initially there was no prohibition on the use of alcohol in Islam. One of the early suras (chapters) of the Qur'an mentions wine (khamr) in a "positive" context as one of the drinks promised to the Godfearing in paradise (Qur'an 47:15), ${ }^{3}$ and as one of Allah's signs of grace to humanity (Qur'an 16:67). Hadith indicate that Hamzah, the uncle of the Prophet, and another companion, Anas ibn Malik ibn Nadar al-Khazraji, were once found in a state of intoxication. One of the sacred stories relates that some warriors for the faith used alcohol before the Battle of Uhud (Sahih al-Bukhari: "Kitab Fard al-Khumus"; Sahih al-Bukhari: "Kitab al-Jihad"; Sahih Muslim: "Kitab al-Ashriba," etc.). Similar information can be found, for example, in al-Tabari's tafsir (exegesis). His work mentions the mistakes of the first Muslims in ritual prayer, which were caused by a state of intoxication (Wensinck 1997, 994).

Subsequently the situation changed. Wicked works committed by those who were in a state of intoxication overshadowed the useful properties of wine. The use of khamr was forbidden (Qur'an 2:219; $4: 43 ; 5: 90-91)$. It is not surprising that there was no ban initially: the Muslim community received individual concepts and guides to action incrementally and as necessary.

After the death of the Prophet, the jurists of Hejaz came to the conclusion that all alcoholic drinks should be prohibited (haram).

1. The period before the advent of Islam. - Ed.

2. Hereinafter, Arabic terms, place names, and personal names will be rendered using a simplified transliteration.

3. It has been noted in exegeses of this hadith that the khamr of paradise is not the same as the khamr that can be encountered on earth. A person cannot become intoxicated or lose one's faculties from its use. 
Later Shafi'i, Maliki, and Hanbali scholar-theologians, as well as their Shi'ite colleagues, confirmed this opinion. At the same time, each of the schools of law utilized their own approaches for reaching that decision, and interpretations of ayahs and hadith served as sources for them. The Arabic verb khamara (meaning "to cover," "to conceal") was derived from the same root as the term khamr (wine) - the only kind of intoxicating substance specified in the Qur'an. Muslim jurists and philologists, using the principle of analogy, determined that khamr is that which clouds the mind and senses. Accordingly, not only the fermented juice of grapes and dates should be considered khamr, but also any substance that causes intoxication and is able to dull the mind and senses. The hadith from Sahih al-Bukhari - "khamr is something that clouds the mind" (Sahih al-Muslim: "Kitab al-Ashriba") - supported the conclusion of the specialists. In their opinion any other substance, such as nabidh (see below for details) that acts on a person in the same way as wine is khamr. Khamr became a generalized term that denoted all alcoholic beverages. This explains why many translators of Arabic sacred texts translate khamr as "alcoholic beverage" or "that which intoxicates."

However, not all theologians agreed with this interpretation. The Mu'tazilite Muhammad al-Jubba'i (d. 915-916) argued in favor of permitting the use of nabidh. He believed that Allah created certain things that resemble those that are permitted in paradise but forbidden on earth, including nabidh, which is not prohibited so that the faithful can comprehend how wine (khamr) will be in paradise (Heine 1993, 840). Being from Basra, al-Jubba'i in part followed the jurists of earlier centuries from his hometown and from Kufa, who were not advocates of the complete prohibition of alcohol. They had concluded that only certain forms of alcoholic beverages, which are clearly identified in the Qur'an and the hadith, are prohibited, whereas others are permissible to use. The most recognizable of them [the jurists] is the eponym of the Hanafi madhab (school of Islamic jurisprudence), Abu Hanifa (d. 767).

Advocates of this point of view put forward arguments in favor of permitting some alcoholic beverages. Firstly, in contrast to representatives of other madhabs, many Hanafi understood the term khamr to mean only that which was revealed to them. In their opinion, applying the term khamr to all substances that have the capacity to cause intoxication is incorrect, and for this reason beverages such as nabidh should not be included in the category of khamr. Secondly, those who opposed the prohibition of the use of any alcoholic beverages regarded some of the hadith cited by their opponents as abrogated (mansukh) or incorrectly interpreted (Long 2014, 80-81). 
Nabidh is a generic term for alcoholic beverages of various kinds produced by means of fermentation, for example, mizr (from barley), bit' (from honey), and fadikh (from different kinds of dates). Such beverages could be prepared from a blend of different ingredients (raisins, dates, and honey). Their composition sometimes included St. John's Wort or cannabis, which produced a hallucinogenic in addition to an intoxicating effect (Heine 1993, 840; Maraqten 1993, 98-99). Quite a few hadith are cited concerning nabidh. Not all of them unambiguously prohibit it, giving cause for some theologians and jurists to permit or preclude the use of nabidh. For example, one of the hadith discusses a straightforward prohibition of the drinking of nabidh prepared in a gourd or a jug that is covered on the inside with "pitch," but at the same time the Prophet did not provide direct instructions on the prohibition of using other forms of nabidh. Intoxication from khalitayn, prepared from two different kinds of dates, is reported in another sacred story. The Prophet banned this beverage then and there (although the hadith mentions nothing about the punishment). Nonetheless, from this report many Hanafis arrived at the conclusion that the Prophet's special ban on the excessive use of just this form of alcoholic beverage points to the absence of a general ban on intoxicating beverages.

Hanafis were the first to claim that texts that ban khamr should be interpreted in a broader context. For them it was significant that nabidh was a common drink in Medina in the days of the Prophet. According to their interpretation, prominent companions such as 'Umar and Abu Dharr continued to drink nabidh after the death of the Prophet. Moreover, while in Kufa, a renowned companion ( $a s h a b$ ), the jurist Ibn Mas'ud, reportedly expressed the view that this drink was legal, although he himself did not use it. Many jurists in Iraq followed this example and began to assert that the prohibition on khamr did not refer to nabidh (Rabb 2015, 145-47).

To be clear, Abu Hanifa did not refute the standard opinion that khamr and intoxication are unacceptable, that it is haram. Hanafis were united in this issue with representatives of all the madhabs. The principal difference of opinion of some of the Hanafis lies in the fact that it was not the drinks themselves that were prohibited, but the effect of the drinks (that is, intoxication). That said, there were also authoritative scholars among the Hanafis, such as Abu Khanifi Muhammad al-Shaybani (d. 804-5), who supported the prohibition of alcohol.

There is another important dimension: what is considered intoxication? Every legal school expressed an opinion on this question. 
From the point of view of Abu Hanifah, intoxication is the state of a person when "intellect has left him so he does not understand a little or much (anything at all)" (Long 2014, 83). ${ }^{4}$ It should be noted that all madhabs provide punishment ${ }^{5}$ for the use of alcoholic beverages or the state of intoxication.

Thus, in accordance with three Sunnite madhabs, anything that intoxicates is prohibited, even in small quantities. Shi'ite theologians also adhered to the same view. In conformity with the norms of Sharia, wine and other forms of alcohol are unclean (najis) and their use prohibited (haram). However, they do not take a Muslim beyond the bounds of Islam: he or she does not become an unbeliever (kafir) but is considered impious (fasiq). In some Hanafi texts and particularly in early ones, alcoholic drinks that are not prohibited explicitly are permitted under certain circumstances, but not in intoxicating amounts. 6

However, the well-known Swiss Orientalist Adam Mez, describing the daily life of Muslims of the third through fourth centuries AH (the ninth through tenth centuries CE), and citing a multitude of examples concerning representatives of all social strata, wrote that "despite the Qur'an's prohibition, wine drinking was prevalent at that time." According to the testimony of al-Muqaddisi, even people worthy of respect (masha'ikh) did not renounce wine in Old Cairo. The Baghdad vizier al-Muhallabi drank together with local qadis and with the members of the supreme qadi. Caliphs also drank alcohol (Mets 1973, 319). Some argue that representatives of the upper classes drank from a sense of superiority, taking pleasure in alcohol as one of the privileges granted to the elite (khass) in Islamic countries. Abstinence was regarded as the duty of common people ('awam), who were not able to control themselves (Matthee 2014, 104).

A little later, at the turn of the eleventh century, Ibrahim al-Raqiq al-Qairawani (of Tunisia) wrote a work devoted to wine (Maraqten 1993, 95). His follower, the Egyptian Muhammad ibn 'Usman al-Imam al-Nawagi (d. 1455), was subjected to serious criticism for his work of "unrestricted" content, but he was not executed nor even forced to

4. The Dagestani scholar-theologian Muhammad al-Quduqi explained one of the definitions of intoxication according to the Hanafi madhab: "The state when a person cannot distinguish a man from a woman and heaven from earth."

5. From twenty to eighty blows of different intensities with a whip or a stick depending on the madhab, legal status, and state of health of the punished.

6. The position of the Hanafi scholars concerning the use of alcohol eventually moved closer to the view of representatives of the other madhabs. 
go into hiding; he simply changed the title of the essay, making it less provocative (Van Gelder 1995, 225). If drinking wine makes a Muslim impious (fasiq), then his exhortation to drink conflicts with Islamic dogma and leads to kufr (that is, unbelief). For this reason he could easily have been punished.

The historical examples above may be misleading. In accordance with the norms of Sharia, drinking wine (and its production, trade, etc.) was, of course, prohibited at the religious and state levels, and it was also censured by society. Those authors cited above provide evidence of this. In general, caliphs struggled both with their own weaknesses and wine drinking. With respect to the work of al-Nawagi, a contemporary issued a fatwa that almost exceeded it in size (Van Gelder 1995, 225). Individual examples of works devoted to wine cannot be compared with the thousands of others in which the drinking of wine was prohibited.

Regional characteristics should also be mentioned. For example, wine drinking was punished in the Hejaz, "while in Mesopotamia they did not find anything wrong with it" (Mets 1973, 320). In the Ottoman Empire - the successor of Sunni orthodoxy - the Qur'anic prohibition was carefully observed; the annals of its history are full of information about the persecution of those who dared to use the banned beverages. At the same time, as a multiethnic empire, it absorbed numerous communities of different faiths, representatives of which used these drinks widely. Both those for whom the use of alcohol was prohibited and those for whom it was entirely legitimate could be among the inhabitants of a city or even a quarter (Georgeon 2002, 7).

With regard to Dagestan, the history of the daily life of its population is practically unstudied, and this is particularly the case with respect to the consumption of alcoholic beverages. Although written sources and artifacts on this question are few, they nonetheless exist. Excavations at Derbent revealed fragments and complete exemplars of stone and ceramic wine presses that date to the eleventh through the beginning of the thirteenth century. ${ }^{7}$ Nutsal Andunik of Khunzakh's will notes that "in $890 \mathrm{AH}$ [1485 CE], vizier Qadi 'Ali-Mirza of Andi, during a meeting of lords on Mount Andi," mentioned grapes that were under cultivation in the territory he governed (Khashaev 1967, 135). The Georgian metropolitan Kirill, who visited the embassy in Muscovy, reported that "in Buynak ... there are many grapes, arable lands, and forests" (Snosheniia Rossii 1889, 401). Buynak was regarded

7. Unpublished material. Verbal communication with Professor M. C. Gadzhiev, doctor of the historical sciences and head of the archeology department of IIAE DNTs RAN. 
as the possession of the shamkhal8 and main qadi of its state, Ali al-Baghdadi (who became a qadi no later than $1635 \mathrm{CE}$ and died in 1655) (ad-Durgeli 2012, 27, 39). Al-Baghdadi denounced an addressee in poetic form because "he allows people to commit the illicit" - to drink alcoholic beverages and to smoke (al-Ghumuqi, 11-12). For this reason we may assume that the grape was not only cultivated as a berry but also for the production of alcoholic beverages. The European traveler Adam Olearius, who visited Tarki in $1638 \mathrm{CE}$, wrote, "The vessels they have for drinking are long cow horns from which they drank a beverage they called braga, ${ }^{9}$ which is distilled from millet and has a color and consistency that resembles brewer's yeast. They also drank vodka ${ }^{10}$ from these vessels with gusto, so they all quickly became very drunk and made such a noise that they could barely hear their own words in spite of the presence of their prince" (Podrobnoe opisanie puteshestviia 1870, 988). Describing the "Koysu fortress" situated six hours from Endirey, which he visited in 1666, the Ottoman traveler Evliya Çelebi wrote, "In this city . . . they do not drink any wine or spirits. They do not know about all the means of intoxication, but the dissolute [people] drink kumiss and bouza. ${ }^{11}$ Ulema and elderly people drink a dense [dark] sweet bouza called maksheme [in another text Çelebi called it makseme] (Chelebi 1979, 118). ${ }^{12}$ P. G. Butkov, who has studied archival material of past centuries, writes that "Peter the Great found outstanding grapes in Derbent (in 1722 - M.M.) and regretted that they could not make good wine from them" (Materialy dlia novoi istorii Kavkaza 1869, 148).13 J. A. Güldenstädt, who gathered information on Dagestan at the beginning of the 1870 s while in Transcaucasia, noted, "In the region of Ansokul by the river there is the village of Kharakan and

8. Shamkhal is a title of rulers of the shamkhalate in Dagestan. - Ed.

9. "They" meaning the Russians; braga (brazhka) is a beer drink, a product of incomplete fermentation.

10. They purchased vodka in the city of Terskii, a Russian outpost in the Eastern Caucasus.

11. Bouza is defined in the Bol'shoi sovetskoi entsiklopediia [Great Soviet Encyclopedia] in this way: "bouza (Turkish) a beverage, is prepared from millet, buckwheat, or oat flour, like beer but without hops. Bouza contains 4-6\% alcohol. Bouza is prevalent in Crimea, in the Caucasus, and to a lesser extent in Turkmenistan." In Dagestan it was also prepared using hops.

12. Bouza is called "makhsymae" in Ossetian. The term is assonant in many Indo-European languages and, it appears, has the same root.

13. In Dagestan chikhir' (Turkish) was produced - a young wine from incomplete fermentation and was in essence grape juice or must. It was low alcohol and spoiled quickly. 
fourteen others .... Wine and fruits are encountered in this region" (Gil'denshtedt, 2002, 247). This fragmentary information is evidence of the fact that the local population used alcohol both on the plain and in the mountains and mountain valleys of Dagestan and that it was of various types. The research of ethnographers who have recorded a significant variety of alcoholic beverages indicates this (Alimova 2005, 95-96; Ramazanova 2011, 139-45; Musaeva 2003, 121-23) as does folklore. For example, there is a well-known legend in which an Arabic theologian arrived in Dagestan together with the jurist Ibrahim-Hadji al-'Uradi (d. 1770-1771). In the morning they set off together for special lodgings (in Avar, qul'a) to perform a ritual ablution. It was so cold that Ibrahim-Hadji had to break a thin layer of ice in order to immerse himself in the water. The Arab was extremely cold, and on arriving home Ibrahim-Hadji gave him a type of bouza (in Avar bakqva-chha'a) ${ }^{14}$ to drink for warmth. The Arab drank it and said, "There it is forbidden (haram) but here it is permissible (halal)."15

It is difficult to imagine that Ibrahim-Hadji al-'Uradi supported permitting the use of alcoholic beverages. He is known as a theologian with "radical" views that are clearly revealed in his legal opinions, particularly in regard to the necessity of military campaigns in Transcaucasia, wherein he disputed the opinion of his contemporary Dawud-Hadji al-Usishi (d. 1757) (Musaev 2013, 3225-26). The qasida of the latter contains these words: "We drank and from that we became drunk. That which intoxicates poured on us like rain from heaven." Considering that the author uses the first person plural personal pronoun, one may suppose that it is not about him but about Dagestani society in general. But along with this he writes: "this is Dawud-Hadji's qasida in which he turns to the Almighty and repents for sins that have been committed" (ad-Durgeli 2012, 48).

A well-known expert on the history and written culture of Dagestan, Ali al-Ghumuqi (Kayaev, d. 1943) wrote about the theologian Hasan al-Kudali (d. 1795): "Sometimes, taking one of his students as a traveling companion, he set off for the city of Alkhatsikhe (Akhiskha), ${ }^{16}$ spent the winter there, taught, and then returned home. It is said that

14. Bouza is not completely fermented, and even children drank it.

15. The story is known in Dagestan and is often used jokingly by lovers of alcohol as a "justification" for their actions. (Communicated by M. G. Shekhmagomedov, junior researcher at IIAE DNTs RAN.)

16. It was located in the Ottoman Empire and now in Georgia. 
[Hasan al-Kudali] sometimes drank alcoholic beverages (khamr), ${ }^{17}$ known as bouza and produced in Dagestan, in small quantities as well as other [wine]" ('Ali al-Ghumuqi, 48).

Hasan (the Elder) al-Kudali was the author of various works including legal papers. If a well-known theologian in Dagestan used alcoholic beverages and had found a justification within the framework of Islamic law, then one may infer that some part of the population also had a propensity for drinking bouza. A contemporary of Hasan, Abu Bakr al-Aymaki (d. 1791), who had a friendly relationship with him, wrote,"I'lam al-tilmidh bi ahkam al-nabidh" [A student's letter of advice on determinations regarding nabidh] - a legal essay that considers the issue of nabidh, understood as bouza in Dagestan. Abu Bakr wrote his work in 1777 with the intention of eradicating the practice of some teachers and their students concerning the permissibility of drinking nabidh. With an explanation for every issue, the scholar-jurist cited quotations from the Qur'an and Sunnah, as well as pronouncements of authoritative scholar-jurists of all four madhabs. He wrote:

I am surprised when I see scholars of Dagestan and their disciples, not to mention the people of Dagestan as a whole, who are indifferent to the commands of Sharia, in particular those who drink nabidh, who are drawn away from an understanding of Allah; Dagestanis do not greet a guest without offering nabidh until he gets drunk and becomes a laughingstock for the people. This is not acceptable to reason, not to mention Sharia.

Abu Bakr indicated that Abu Hanifah permitted the use of beverages not obtained from grapes or dates if the purpose of their use was not for amusement and revelry. At the same time, however, al-Aymaki believed that Abu Hanifah's pronouncement should not be understood as allowing nabidh, which was in conflict with Sunnah.

"Know that anything that intoxicates is prohibited. The ban is established by the four foundational sources of Islamic law - the Qur'an, Sunnah, ijma, and qiyas .... Apparently," continues Abu Bakr, "certain hadith did not reach Abu Hanifah, who lived before the three imams of the other madhabs, such as: 'That which intoxicates by use in large quantities is banned also in small [quantities]'; 'Beverages obtained from wheat,

17. Ali al-Ghumuqi understood khamr to mean any alcoholic beverage. 
barley, dates, raisins, grapes, and honey are wine, and I (the Prophet) prohibit all that intoxicates"' (Guzbulaev 2005, 38-39; IIAE DNTs RAN, f. 14 , op. 1, d. 88).

Yusuf al-Salti was another contemporary of Ibrahim al-'Uradi, Dawud al-Usishi, Abu Bakr al-Aymaki and Hasan al-Kudali. Yusuf and Hasan lived in populated areas located several kilometers from one another, and "scholarly disputes took place between them on various issues. It is said that Hasan al-Kudali once showed flexibility and, upon reflection, gave his opponent credit and said, 'I will leave a place here for the leather tanner so that he may express [his opinion].'. . . By leather tanner he meant Yusuf al-Salti because that is one of the main trades of the people of Salti. [Yusuf] was a student of two prominent scholars - Dawud al-Usishi and Ibrahim al-'Uradi. Al-Salti was the author of several works, including some on the prohibition of [the use of ] wine" (al-Ghumuqi, 53).

The ulema mentioned above are among the recognized Dagestani theological authorities. At the same time, some of them remained within the context of the local culture of drinking 18 and ventured to use bouza themselves, not considering this in conflict with religious norms. The presence of the aforementioned essays by al-Aymaki, al-Salti and al-Awari indicates the relevance of the question of the use of certain forms of alcoholic beverages. Legal decisions were not imposed without cause, just as they did not write lengthy legal essays without necessity. The latter were created above all for the scholarly community and were intended as a guide in explaining the tenets of faith to the Dagestani population.

In the eighteenth century Dagestan was not a unified governmental and legal entity. Nonetheless, it continued to be one "country." It is difficult to imagine that the opinion of the ulema that made the appeal not to drink alcoholic beverages could be heard when there where those among the Dagestani theologians who themselves drank. Moreover, opposing views could exist even within a single family, as, for example, in the family of hereditary theologians of al-Awari. The qadi of the Avar Khanate, Dibir-Qadi al-Awari (d. 1817), gathered excerpts from theological and legal essays and the pronouncements of Muslim authors in support of the prohibition of the production and drinking of wine. The text was titled, "Taqrirat fi tahrim al-khamr 
wa shurbihi" (Conclusions on the prohibition [of the production] and consumption of alcoholic beverages) (Shikhsaidov and Omarov 2005, 70-71). It contains the conclusions of Dibir-Qadi al-Awari including those on the prohibition of nabidh. However, his younger brother Nur Muhammad al-Awari (d. 1834), who was the next qadi of the khanate, drank alcohol (for further details see below).

There were in fact ulema whose words conflicted with their actions, and so the appeal of one of the qadi to his flock is not incidental: "Listen to what scholars say and do not watch what they do themselves" (Omarov 1868, 21).

There is a very interesting case recorded in a biographical work by Ali al-Ghumuqi (Kayaev):

Abdallah al-Sughuri, nicknamed "Satan," ... reached great heights and perfection in the sciences. At the same time he got carried away with alcoholic beverages and lacked willpower to such an extent that he drank away his household goods. Then he reached the point that he stole some of his wife's property that fell into his hands. He sold that and bought intoxicants. When his wife found out about this she objected to it but could not change anything.

The scholar Nuzur al-Sughuri told me that [Abdallah] sometimes took an annual trip to an alliance of communes, Khindalal (Qoysubu), in which vineyards grew and alcoholic beverages were made. He took his journey every fall in order to drink wine there and take it back with him, after which he returned home. All this ended after Imam Hamzahbek established Sharia law there. Subsequently, [Abdallah] saw people there whom he had not seen earlier and who paid no attention to him. He observed that all the inhabitants [of Khindalal] became murids ${ }^{19}$ who began to wrap their papakhas (Astrakhan hats) with a turban, which Dagestanis had not done before, except those who visited Mecca and performed the rites of hajj. Abdallah noticed that all the inhabitants [of Khindalal] repented of the use of wine, smoking, and other things that conflicted with Sharia that they were involved in earlier. They began to follow the religion, worshipped [Allah] and [began to perform] dhikr. ${ }^{20}$ Abdallah was very surprised by this.

19. Those committed to a spiritual path, particularly in the Sufi tradition. - Ed.

20. Dhikr is the practice of meditating on the names or attributes of Allah; it is a spiritual exercise whose goal is to feel the presence of Allah within oneself and to be focused on Allah. Generally $d h i k r$ is rhythmic and connected with repeatedly breathing an iterative remembrance of the names of Allah (asma'al-husna) or phrases that contain the name of Allah. 
One day Abdallah came to them on a Thursday. He noticed that they believed this day was Friday and gathered to begin Friday prayer. Abdallah watched their actions, got out of their way, sat, and began to observe them, marveling at their blunder with regard to [the day of] festive prayer. Then, when they entered the mosque, he went in together with them, performed Friday prayer, left earlier than them, and sat near [the mosque]. Afterward, when people left the mosque they approached him and began to exhort him to stop drinking wine. They admonished him, noting his deep knowledge, and said that owing to this knowledge he possessed, he should confess before the others and stop drinking wine. He listened to them until they stopped their speech, their exhortations, and their reproaches of him regarding his sins. He told them that he accepted their admonitions and thanked them for this. Then he said to them, "I also want to leave you a bequest and I hope that you accept it just as I accepted your exhortations." They asked: "What is this bequest?" Abdallah responded, "I instruct you not to perform Friday prayer on Thursday, earlier than prescribed according to the Sharia of time." He repeated this to them, pointed to their mistake, shamed them and after this they parted" (al-Ghumuqi [Kayaev], 69).

This story is also in circulation in an oral form as a legend. In it, it is said that when the people from Khindalal reproached him for his use of alcohol, he responded: "Heqolev dun 'antav vatani, khamiz qoyatl ruzman balel nuzh shchal kkolel?" (in Avar) - "If I who get drunk am a fool, then you - who then are you, who perform Friday prayer on Thursday?"

Perhaps the best known of the lovers of alcoholic beverages among Dagestani theologians is the scholar, teacher, and political figure Sa'id al-Harakani (d. 1834). He was the grandson of Abu Bakr al-Aymaki, who wrote an article that criticized the use of nabidh (see above). Ali al-Ghumuqi (Kayaev) wrote that Sa'id learned to drink bouza from his teacher Hasan al-Kudali:21

Sa'id was an eloquent person. He could speak softly like the rulers with whom he had good relations. He enriched their society with his presence

21. 'Ali al-Ghumuqi (Kayaev) wrote (p. 79), that Sa'id al-Harakani, in turn, instilled in his student Abdulkhalim al-Tsuishi a passion for alcohol: "[Abdulkhalim al-Tsuishi] like his teacher Sa'id al-Harakani, drank a little alcohol and issued a fatwa on the permissibility of this. [Consuming alcohol] became a habit for him. Before the start of a lesson, he sometimes 'scented himself with perfume,' and then began the lesson. $\mathrm{He}$ said that [alcohol] makes him more energetic in teaching." 
and sometimes even permitted himself to drink [alcoholic beverages] with them. He issued a fatwa permitting some of them to be drunk in non-intoxicating doses, although no one adhered to the [established] limits, and they often reached a level of intoxication (al-Ghumuqi, 55).

When Imam Ghazi-Muhammad began to establish Sharia, as he understood it, throughout Dagestan, Sa'id al-Harakani harshly criticized his actions. For this the imam "drove Sa'id Effendi from [his] home, and imprisoned his son" in the beginning of 1830 . Meanwhile, the imam ordered all the wine kept in his home to be poured out onto the ground (Gammer 1998, 84; Dvizhenie gortsev 1959, 130). Hamzah-bek, who subsequently became the successor of Ghazi-Muhammad, carried out the punishment. In addition, they were both students of Sa'id. There is a story that Sa'id met a woman on his way home to Arakani who informed him with malice about the destruction of his library: "Sa"id, it seems your manuscripts are floating in wine." $22 \mathrm{He}$ did not betray his sorrow and responded, "Well, so be it! They deserve that - after all, they contradicted one another" (Shikhsaidov, 149). In despair, hoping for the return of his main property, books, Sa'id al-Harakani complained to his patron Aslan-khan al-Ghazi-Ghumuqi, a colleague and pupil of Muhammad al-Yaraghi, and another pupil, Shamil, who, as is known, in turn became the next imam (Kasumov and Gichibekova 2012, 21).

Ghazi-Muhammad waged a relentless campaign against the consumption of alcoholic beverages; Hamzah-bek continued it, although it is said that before he became an imam, he allowed himself to drink nabidh. Shamil led this fight with redoubled energy, employing Sharia norms of punishment like his predecessors. It should be noted that according to some reports, the fathers of Ghazi-Muhammad and Shamil liked to drink. The father of the first, although well versed in religious matters, led a carefree life and often drank alcoholic beverages. Khasanilav from Gimry states that he [Ghazi-Muhammad's father] burned nine homes of fellow villagers who were at odds with him while in a state of alcoholic intoxication. Ghazi-Muhammad scolded his father but could not influence him (IIAE DNTs RAN f. 1, op. 1, d. 84, 1. 15, 20-21, and elsewhere; Chichagova 1889, 15).

It is apparent from information provided by the aforementioned Khasanilav that Ghazi-Muhammad's prohibition on drinking alcohol was introduced gradually; it is possible that he acted according to the example of the Prophet. At first the use of low-alcohol bouza was allowed

22. We should bear in mind that "floating in wine" is an allegory. 
and then a complete ban was introduced. For a characterization of the first stage of Ghazi-Muhammad's struggle against alcohol the following case is striking. When merchants from Gimry went to Derbent for textiles, they turned to the imam with the question: "Is it possible to allow us to drink a little?" Ghazi-Muhammad advised them to appeal to the local mullah, who, as a native of Khunzakh, "was accustomed to drinking." The mullah asked [them] to bring drinks - vodka and filtered bouza. After this he drank them together with those present. They became drunk "until they collapsed" (Gasanilau [Gimrinskii]; IIAE DNTs RAN, f. 1, op. 1, d. 84, 1l. 96-97).

A familiarization with sources and materials on the history of Dagestan of the first half of the nineteenth century reveals that the use of alcohol was a rather widespread phenomenon. The Memoirs of Abdullah Omarov, in which he describes the 1840s-1850s, indicate that bouza was a part of the traditional culture. A wedding, a celebration of the birth of a son, or any celebration in general could not do without it. Bouza was even given to a teacher for teaching religious studies. Representatives of all social strata drank - uzdens, khans, and raiyas. 23 Notwithstanding the presence of strict ceremonial frameworks, they might even drink alcohol during religious holidays. Thus, Omarov wrote, in Kazanishche during the Muslim holiday of breaking the fast (Eid al-Fitr, known locally as Uraza Bayram), "it was difficult to encounter five people, of which two were not drunk."

With the development of economic contacts with Russians, wine, vodka, rum, liquors, and balsams gradually entered into use (Omarov 1868, 17, 24, 29, 30, 39, 52; Omarov 1869, 28, 42-43). In his Notes, A. P. Ermolov, the commander of the Russian troops in the Caucasus, wrote, not without satisfaction: "But debauchery from the use of hot drinks for which they have a great passion [he means people from Akushin - M.M.] is beginning to take root. Up to now our treasury wine serves as the most luxurious [drink] and perhaps the only thing that saves them is the fact that the vice-governors sell water instead of vodka!" (Zapiski A. P. Ermolova 1991, 350).

The use of stronger alcoholic beverages resulted in the transformation of a celebratory meal intended to amuse the revelers into a social evil. They saw Russian influence as the cause, and this may have played a precipitating role in the expansion of the liberation movement in Dagestan in the second half of the 1820s (Magomedov 2015, 135-39). 
Moreover, existing social attitudes dictated that a devout Muslim should not consume alcohol. Thus, for example, one student of a madrassa, wanting to appear devout, did not even eat food from yeastleavened dough. ${ }^{24}$ Others, from "decorum," supervised entertainment functions from the outside (Omarov 1868, 54-56; Omarov 1869, 43).

Ghazi-Muhammad was not the first ruler who struggled with the circulation of alcohol. Surhkay II "Kunbuttay," khan of Ghazi-Ghumuq, banned the purchase of vodka ('araq) and wine under the threat of a fine at the rate of one bull by special rule in 1813. Individual communities introduced similar customary laws ('adat). For example, the community of Orota reached a decision to exact a cow "from one who drinks wine ... and from one who makes wine at home, even if in a small quantity" (Aitberov 1999, 106-7). ${ }^{25}$ Taking into consideration the fact that the use of alcohol had a mass character and that some ulema used it, the presence of texts in which this fact is justified appears logical.

The legal views of the aforementioned Nur Muhammad al-Awari (d. 1834) on this issue are interesting. In his work he criticized Imam Ghazi-Muhammad for corporal punishment, which was introduced due to the use of alcoholic beverages. Nur Muhammad's position consisted in the following:

1. If a person is a confirmed Hanafite who in accordance with the madhab is permitted to use non-intoxicating quantities of a beverage, 26 and he has consumed an intoxicating amount of a beverage (besides wine, which is prohibited), then he should be punished according to Sharia, but "his witness [shahada] 27 is accepted."

"You," wrote al-Awari, referring to Ghazi-Muhammad, "should know the attitude of the Hanafi scholars on the issue of drinking alcohol and the punishment for this action. In particular Imam Abu Hanifah believes that punishment for drinking is obligatory only for wine (khamr). And for drinking other beverages a person is punished only if he becomes drunk."

2. Drinking non-intoxicating amounts, with the exception of wine, is a minor sin (saghira) and not a major sin (kabira).

24. Yeast was obtained when preparing bouza.

25. The author of the publication dates the source to the 1810 .

26. It follows from the works of Dagestani ulema that they were oriented toward the view of those Hanafi theologians who did not forbid the use of some alcoholic beverages in non-intoxicating doses.

27. The shahada is the Muslim profession of faith, one of the five pillars of Islam. - Ed. 
In his conclusions Nur Muhammad al-Awari cited a great number of works of the best known Shafi'i jurists.

"These arguments are more than sufficient for me," wrote Nur Muhammad,

I hope that the Almighty does not punish me for drinking nonintoxicating amounts of nabidh, the prohibition of which is debatable. I am following Abu Hanifah on this question. ... If a person performs an action following a madhab allowing this action, yet there are disagreements among scholars regarding its permissibility, it is not a considered a sin for him, since the following [taqlid] [of the madhab's opinion] is well grounded. ... If a person sees someone drink nabidh, then it is not possible to condemn him, since perhaps he is following the view of Abu Hanifah in this matter (al-Awari).

It is possible Nur Muhammad was familiar with the judgment of the Dagestani scholar-theologian Muhammad al-Quduqi (d. 1717), passed at the end of the seventeenth century. At the very least their conclusions are similar: although they use a different argumentation and different sources, both were Shafi'i theologians.

In his conclusion Muhammad al-Quduqi first explained the difference between the opinion of Shafi'i and Hanafi scholars regarding the use of alcohol and further suggested:

Muslims, including ascetic Sufis, ${ }^{28}$ should not blame someone for the fact that they drink alcoholic beverages in a quantity that does not result in intoxication .... It is preferable not to consume drinks about which there is no unified scholarly opinion. It is also preferable not to condemn and debate those who use them in non-intoxicating quantities. Courts (qadi) or rulers (amir) have the right to that (to judge and to determine the rules).

Further, the author focused on the status of the Hanafite and Shafi'ite who use nabidh in non-intoxicating doses: whether their testimony (shahada) is accepted or not has important legal consequences in the context of Islam (an acknowledgement of the validity of agreements and so on). Muhammad al-Quduqi cites a quotation from the work of one of the jurists and provides an explanation:

28. It is stressed that Sufis adopted an uncompromising position with respect to the use of nabidh. 
"If a Hanafite drinks a small quantity of nabidh, then he should not be considered impious (fasiq). Accordingly, his witness (shahada) is accepted. But if he became drunk, then he should be punished, since intoxication is a sin (haram). However, if one who regards nabidh as prohibited drinks, for example a Shafi'ite, then his witness (shahada) is not accepted. Some say that it is accepted.” In other words, this opinion is disputed. From the words of the imam al-Shafi'i it follows that the witness is accepted.

Considering what is unlawful as permitted is a greater sin (haram) than committing the given sin. If a person considers adultery (zina) to be permissible, then he becomes an unbeliever (kafir), and if he commits adultery, then he does not.

The Shafi'i madhab accepts the witness (shahada) of a Hanafite (that is, one who considers a small quantity of nabidh permissible). Nevertheless, recognizing the illicit as permissible is a great sin from the point of view of the Shafi'i madhab. A Shafi'ite who drinks nabidh commits a sin, but this sin is minor, smaller than unbelief ( $k u f r$ ). For this reason, if the witness of a Hanafite is accepted, then the witness of a Shafi'ite who drinks nabidh in non-intoxicating doses should also be accepted. (al-Quduqi)

We have cited extensive quotations from Muhammad al-Quduqi's legal opinions because they spread widely in Dagestan and would have served as a guide for theologians of subsequent generations by virtue of the authority of the author.

Dagestani scholar-theologians were not unanimous in their views concerning the use of alcohol, and some of them did not follow the Shafi'i but rather the Hanafi madhab. Nevertheless, it is indisputable that the view that prevailed was for the total prohibition of alcohol, even in small doses. For example, a theologian of the mid-nineteenth century, Akhmad al-Rugdji, who carried out the functions of qadi in Rugudzha, wrote the work, "Mas'ala fi-l-khubz," in which he considered whether it was permissible to use products of fermentation when baking bread (Gvaramia et al. 2002, 203; Al-Rugdji).

'Umar al-Khunzakhi29 perhaps expressed the views of Dagestani theologians most capaciously on the question of prohibiting the use of alcohol in his "Address" in the genre of nasikhat: 30

29. The authors of the translation identify him as the eighteenth-century theologian, writer, and poet Umar b. Abdusalam ad-Dagistani - a descendent of a Dagestani family that settled in Mecca as far back as the beginning of the seventeenth century.

30. Nasikh or naskh is a form of moral instruction in Islamic law that investigates material that seems contradictory. - Ed. 
With regard to the judgment concerning the consumption of intoxicating beverages, it is forbidden in accordance with the text of the hadith, that reads:

"Anything that intoxicates is wine, and all wine is prohibited." From this it follows that any intoxicating beverage is also prohibited. Drinking it is prohibited. A person who does disregards religious commandments. Imam al-Shafi'i refers to alcohol as sewage, comparing it with human feces. There are many hadith about the prohibition of spirits. Thus far the issue has been the drinking of the common people. With regard to scholars, even a small sin becomes big because this follows from the books on tawhid (dogmatics), since they are an example for others, as communicated in the following hadith: "Whoever set a bad example receives a punishment for this and for whomever followed his example until Judgment Day. Moreover, those who followed him also receive a punishment." And you, the people of Dagestan, cast aspersions on Musalav (Muhammad al-Quduqi - M.M.) and Damadan [al-Mukhi] (d. 1724), claiming they allowed themselves to drink both this and that (alcohol). And in reality, those who attribute this action to these people are liars and offend the honor of these accomplished scholars. And if they committed such an action, then they erred in this. But they (i.e., prophets) and imam-mujtahids are not infallible; they are merely followers of the madhabs of those imams. And if a follower [muqallid] is mistaken in his conclusions and pronounces a judgment that contradicts that of his imam, then we may not follow his word (Abdulmazhidov and Shekhmagomedov 2013, 133).

In summary, we can come to the following conclusions. In spite of the fact that the inhabitants of Dagestan followed the Shafi'i madhab, in which the production and consumption of alcoholic drinks is prohibited, there are numerous reports that in the seventeenth through the first half of the nineteenth centuries they were produced and used. This is also the case for wine, which was prohibited by all Muslim legal schools. Some Dagestani theologians drank nabidh (bouza), finding justification for this in the fact that they followed the Hanafi madhab on this issue. In classical works, representatives permitted the drinking of some forms of alcoholic beverages in nonintoxicating doses.

Among Dagestani scholar-theologians the opinion was widespread that the use of any alcoholic beverage is forbidden (haram) but that this is a minor sin, since the witness (shahada) of such a person is accepted. They thought that if a person followed the Hanafi madhab, 
then it was permissible to use alcoholic beverages that did not belong to the category of khamr, in non-intoxicating portions. It appears that the explanation of this position must be sought in the undesirable legal implications of the rejection of the testimony (shahada) of people who drank nabidh, which was a widespread occurrence.

Some Dagestani scholar-theologians wrote works justifying a full ban on the use of alcohol, including in the smallest portions. They believed that the testimony (shahada) of someone who uses alcohol in any amount is not accepted. In some feudal estates, alliances of communes and individual communes introduced local bans on the use of alcohol that did not make provisions for Sharia forms of punishment (hadd). Imams (Ghazi-Muhammad, Hamzah-bek, and Shamil) introduced a complete prohibition on the production, trade, and use of alcoholic beverages. Individuals who violated the ban were punished in accordance with the norms of Sharia. The legal opinions and fatwas of scholar-theologians did little to influence the everyday practice of using alcohol by the local population. They became more effective when they were supported by state and legal coercion.

\section{References}

Archival Materials

al-'Aymaki, Abu Bakr. "I'lam al-tilmidh bi ahkam al-nabidh" [Arabic]. Institut istorii, arkheologii i etnografii Dagestanskogo nauchnogo tsentra Rossiiskoi akademii nauk (hereafter IIAE DNTs RAN). Fond vostochnykh rukopisei, f. 14, op. 1, no. 88.

al-Awari, Nur Muhammad. "Taqrirat” [Arabic]. IIAE DNTs RAN. Fond vostochnykh rukopisei. Kollektsiia M.-S. Saidova, no. 39.

al-Ghumuqi (Kayaev), 'Ali. “Taradjim ‘ulama’ Daghistan” [Arabic]. Personal collection of I. A. Kayaev.

al-Quduqi, Muhammad. “Taqrirat fi mas'alah al-nabidh” [Arabic]. Digital copy. Personal collection of M. G. Shekhmagomedov.

al-Rugdji, Ahmad. "Mas'ala fi-l-khubz" [Arabic]. Gruzinskii natsional'nyi tsentr rukopisei. ArL no. 463.

Gasanilau (Gimrinskii). Imam (Kazi-Mulla) Gazimuhammad. Translated from the Avar language by Bagadur Malachikhanov. Makhachkala, January 27, 1936. Arkhiv IIAE DNTs RAN, f. 1. op. 1, d. 84.

Literature

Abdulmazhidov, R. S., and M. G. Shekhmagomedov. 2013. "Obrashchenie Umara al'Khunzakhi k zhiteliam Dagestana: Obshchaia kharakteristika i kommentirovannyi perevod" ['Umar al-Khunzakhi's advice to the inhabitants of Dagestan: General characteristics and annotated translation], Islamovedenie 1: 125-35. 
ad-Durgeli, Nazir [Nadhir al-Durgili]. 2012. Uslada umov $v$ biografiiakh dagestanskikh uchenykh: Dagestanskie uchenye $X-X X v v$. $i$ ikh sochineniia [A journey of the mind through the biographies of the Islamic scholars of Dagestan], translation, commentary, facsimile, indices, and bibliography by A. R. Shikhsaidov, M. Kemper, and A. K. Bustanov. Moscow: Izdatel'skii dom Mardzhani.

Aitberov, T. M. 1999. Khrestomatiia po istorii prava i gosudarstva Dagestana $v$ XVIII$X I X v v$. [Reader on the history of law and the state of Dagestan in the eighteenth to nineteenth centuries], ch. 2. Makhachkala: Izdatel'stvo DGU.

Alimova, B. M. 2005. Pishcha i kul'tura pitaniia u tiurkoiazychnykh narodov Dagestana $v X I X$-nachale $X X v$. [Food and the food culture of the Turkic-speaking people of Dagestan in the nineteenth to the beginning of the twentieth century]. Makhachkala: ID Nauka plius.

Chichagova, M. N. 1889. Shamil' na Kavkaze i v Rossii: Biograficheskii ocherk [Shamil in the Caucasus and Russia: Biographical essay]. St. Petersburg.

Dvizhenie gortsev Severo-Vostochnogo Kavkaza v 20-5o gg. XIX v.: Sbornik dokumentov. 1959. [The movement of the mountaineers of the Northeastern Caucasus during the 1820 to 1850s: Collection of documents]. Makhachkala: Dagestanskoe knizhnoe izdatel'stvo.

Chelebi, Evliya [Evliya Çelebi]. 1979. Kniga puteshestviia. (Izvlecheniia iz sochineniia turetskogo puteshestvennika XVII veka) [Seyahatname (Excerpts from the writings of a Turkish traveler of the seventeenth century)]. Vol. 2, Zemli Severnogo Kavkaza, Povolzh'ia i Podon'ia [Lands of the Northern Caucasus, the Volga and the Don], edited and translated by A. D. Zheltiakova. Moscow: Nauka.

Gammer, M. 1998. Shamil': Musul'manskoe soprotivlenie tsarizmu; Zavoevanie Chechni i Dagestana [Shamil: Muslim resistance to the tsar; The conquest of Chechnya and Dagestan]. Moscow: Kron-Press.

Georgeon, Francois. 2002. "Ottomans and Drinkers: The Consumption of Alcohol in Istanbul of the Nineteenth century," In Outside In: Marginality in the Modern Middle East, edited by Eugene Rogan, 7-30. London: I. B. Tauris.

Gil'denshtedt, Iogann Anton [Johann Anton Güldenstädt]. 2002. Puteshestvie po Kavkazu $v$ 1770-1773 gg. [Journey to the Caucasus in 1770-1773]. St. Petersburg: Peterburgskoe vostokovedenie.

Gizbulaev, M. A. 2005. Abubakar-khadzhi iz Aimaki - zhizn', tvorchestvo i nauchnoe nasledie [Al-Hadjj Abu Bakr al-Aymaki - life, work and scientific legacy]. Makhachkala.

Gvaramia, R. V., N. G. Kanchaveli, L. I. Mamulia, and L. V. Samkurashvili, eds. 2002. Katalog arabskikh rukopisei Instituta rukopisei im. K. S. Kekelidze (Kollektsiia L Vypusk II) [The catalog of Arabic manuscripts of the K. S. Kekelidze Institute of Manuscripts (Collection 50, Edition 2)]. Tbilisi: Kavkazskii dom.

Heine, P. 1993. "Nabidh.” In The Encyclopaedia of Islam, Vol. 7, p. 840. New York: E. J. Brill.

Kasumov, S., and R. Gichibekova. 2012. "O vzaimootnosheniiakh kadiia Saida Arakanskogo s imamami Gazi-Mukhammadom i Gamzat-Bekom" [On the relationship between Qadi Sa'id al-Harakani and imams Ghazi-Muhammad and Hamza-bek"], Nauchnoe obozrenie: Ezhekvartal'nyi sbornik statei 48: 19-21.

Khashaev, Kh.-M. 1967. Obshchestvennyi stroi Dagestana $v$ XIX $v$. [The social system of Dagestan in the XIX century]. Makhachkala: Akademiia nauk.

Long, M. 2014. “Intoxication.” In Islamic Images and Ideas: Essays on Sacred Symbolism, edited by John Andrew Morrow, 75-100. London: McFarland \& Company. 
Magomedov, A. D. 2015. "Buza, vino ... vodka: Ob odnoi maloizvestnoi stranitse Kavkazskoi voiny" ["Bouza, wine . . . vodka: About a little-known page from the Caucasian War"]. Vestnik instituta istorii, arkheologii i etnografii 43 (3): 135-39.

Maraqten, M. 1993. "Wine Drinking and Wine Prohibition in Arabia before Islam." Proceedings of the Seminar for Arabian Studies 23: 95-115.

Materialy dlia novoi istorii Kavkaza s 1722 po 1803 god P. G. Butkova. 1869. [P. G. Butkov's materials for the new history of the Caucasus from 1722 to 1803.] St. Peterburg: Tip. Imp. Academii nauk.

Matthee, R. 2014. "Alcohol in the Islamic Middle East: Ambivalence and Ambiguity." Past and Present 222, Supplement 9 (Cultures of Intoxication): 100-125.

Mets, A. [Adam Mez] 1973. Musul'manskii renessans [Islamic renaissance]. 2nd ed. Edited by V. I. Beliaev, translated by D. E. Bertel'sa. Moscow: Glavnaia redaktsiia vostochnoi literatury izd. "Nauka."

Musaev, M. A. 2013. "Vzgliad na 'lekianoba' v kontekste izucheniia pravovykh zakliuchenii dagestanskikh uchenykh-bogoslovov XVIII v." [A look at the 'lekianoba' in the context of a study of the legal decisions of the Dagestani scholars of the eighteenth century]. Fundamental'nye issledovaniia 10, part 14: 3223-28.

Musaeva, M. K. 2003. Traditsionnaia material'naia kultura malochislennikh narodov Zapadnogo Dagestana: Panoramnii obzor [Traditional material culture of the small peoples of Western Dagestan: A panoramic survey]. Makhachkala: Izd. dom "Narody Dagestana."

Omarov, A. 1868. "Vospominaniia mutalima" ["Memories of muta'allim"], Sbornik svedenii o kavkazskikh gortsakh 1 (7): 13-64.

Omarov, A. 1869. "Vospominaniia mutalima" ["Memories of muta'allim”], Sbornik svedenii o kavkazskikh gortsakh 2 (6): 1-70.

Podrobnoe opisanie puteshestviia golshtinskogo posol'stva $v$ Moskoviiu i Persiiu $v$ 1633, 1636 i 1637 godakh, sostavlennoe sekretarem posol'stva Adamom Oleariem (per. P. P. Barsova). 1870. [A detailed description of the journey of the Holstein embassy to Muscovy and Persia in 1633, 1636 and 1637, composed by embassy secretary Adam Olearius, translated by P. P. Barsov.] Moscow: Obschestvo istorii i drevnostei rossiiskikh pri Moskovskom universitete.

Rabb, I. A. 2015. Doubt in Islamic Law: A History of Legal Maxims, Interpretation, and Islamic Criminal Law. Cambridge: Cambridge University Press.

Ramazanova, Z. B. 2011. Traditsionnaia pishcha narodov Nagornogo Dagestana $v$ XIXnachale $X X v v$. [The traditional food of the people of the mountains of Dagestan in the nineteenth to the beginning of the twentith century]. Makhachkala: IIAE DNTs RAN.

Shikhsaidov, A. R. 2008. "Said Arakanskii” [Said from Arakan]. In Dagestanskie sviatyni, edited by M. S. Gadzhiev, A. R. Navruzov, and A. R. Shikhsaidov, 2:140-52. Makhachkala: Epokha.

Shikhsaidov, A. R. and Kh. A. Omarov. 2005. Katalog arabskikh rukopisei (Kollektsiia M.S. Saidova) [Catalog of Arabic manuscripts (M.-S. Saidov Collection)]. Makhachkala: Izdatel'stvo tipografii DNTs RAN.

Snosheniia Rossii s Kavkazom: Materialy, izvlechennye iz Moskovskogo glavnogo arkhiva inostrannykh del Sergeem Al. Belokurovym. 1889. [Russia's relations with the Caucasus: Materials found in the Moscow Central Archive of Foreign Affairs by Sergey Al. Belokurov]. Vol. 1, 1578-1613. St. Petersburg: Universitetskaia tipografiia.

Van Gelder, Geert Jan. 1995. "A Muslim Encomium on Wine: 'The Racecourse of the Bay (Halbat al-Kumayt)' by al-Nawāğī (d. 859/1455) as a Post-Classical Arabic Work.” Arabica 42, fasc. 2 (June 1995): 222-34. 
Waines, D. 2011. Food Culture and Health in Pre-Modern Muslim Societies. Boston: Brill. Wensinck, A. J. 1997. "Khamr." In The Encyclopaedia of Islam, Vol. 4, 994-98. Leiden: E. J. Brill.

Zapiski A. P. Ermolova, 1798-1826 gg. 1991. [Notes of A. P. Ermolov, 1798-1826.] Moscow: Vysshaia shkola. 